\title{
SELECTION OF ALTERNATIVE LANDFILL SITE IN KANCHIPURAM, INDIA BY USING GIS AND MULTICRITERIA DECISION ANALYSIS
}

\author{
SURESHKUMAR, M. ${ }^{1,{ }^{*}}$ - SiVAKUMAR, R. ${ }^{1}$ - NAGARAJAN, M. $^{3}$ \\ ${ }^{I}$ Department of Civil Engineering, SRM University, Kattankulathur, Chennai, \\ Tamil Nadu, India \\ ${ }^{2}$ Department of Civil and Structural Engineering, SCSVMV University, Enathur, Kanchipuram \\ Tamil Nadu, India \\ ${ }^{3}$ Soil and Water Management Research Institute, Tamil Nadu Agricultural University, \\ Thanjavur, Tamil Nadu, India \\ *Corresponding author \\ e-mail: sureshgis@kanchiuniv.ac.in \\ (Received $7^{\text {th }}$ Nov 2016; accepted $5^{\text {th }}$ Jan 2017)
}

\begin{abstract}
Identification of suitable landfill site for municipal solid waste disposal is a complex task. The proposal of alternative landfill site consists of multicriterial analysis of various parameters. In this study Geographical Information System (GIS) was utilized effectively for alternative landfill site identification. The analytical hierarchy process (AHP) technique was effectively used by assigning weights and rank for decision making. Criteria such as residential area, road network, Geology, Geomorphology and soil are considered for analysis. The developed system encompasses social, environmental, geological and accessibility conditions. By using this modelling approach, GIS once again proved an effective tool for evaluating multiple criteria in decision making. The research aims to introduce a model for selecting an appropriate landfill site in municipalities. The developed methodology is useful for identifying alternative landfill in the study area with an effective manner.
\end{abstract}

Keywords: pollution, network analysis, buffering, model, solid waste management

\section{Introduction}

Municipal solid waste management is one of the difficult tasks for the local authorities. Starting from planning of solid waste collection up to its disposal, it involves various stages. Because of rapid urbanization in the process of municipal solid waste management is being more tough process. Landfill site selection is one of the most complicated planning activities which should convince many related stakeholders (Eskandari et al., 2012). The urban sprawl emergence to identify the alternative landfill sites for fulfilling the present solid waste disposal requirement. The GIS and AHP method has been properly used in various landfill site identification projects (Sener et al., 2011). Because of the less availability of land for solid waste disposal proper planning is very essential. The process of identifying the alternative landfill site involves more time consuming and tedious process. Selecting the wrong site for landfill may result serious environmental hazards and public opposition (Babalola and Busu, 2011). Assessment on multiple criteria such as residential area, legislation, geology, geomorphology, etc., are required to choose the appropriate site. In developing countries, mostly engineered landfill methods are not adopted due to financial criteria. In this situation, adopting of landfill method is an alternative way for solid waste disposal. In many municipalities the existing landfill sites are already struggling to fit for the present situation. The inability of fulfilling the present 
demand of solid waste disposal, the severe unhygenic condition has been developed. Multicriteria spatial decision support systems help to take a decision in the conflicting problems (Demesouka et al., 2013). The analysis and decision making from the data for alternative landfill identification is a tedious process in conventional methodology. Both spatial and attribute data are considered for analysis in GIS software. High resolution satellite images, digitized maps and field survey information's are incorporated in GIS for decision making. GIS can be effectively used to identify the potential site by multi-criteria decision analysis. Multi criteria decision analysis and GIS were used to identify the landfill site by using suitable weightage (Alanbari et al., 2014). The government has taken many activities to protect the environment and ensure the hygiene in municipalities.

Kanchipuram municipality (Fig. 1) is one of the important place in south India, which

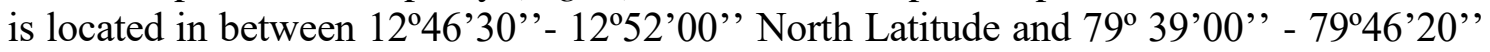
East longitude. Present solid waste generation rate in the municipality is 120 to 130 metric tons per day. The existing solid waste landfill site is in operation from the year 2005 onwards. Nearby to the present landfill site more residential and commercial area are developed due to rapid urbanization. Now the municipality is in situation to identify the potential alternative landfill site to manage the present situation in solid waste disposal.

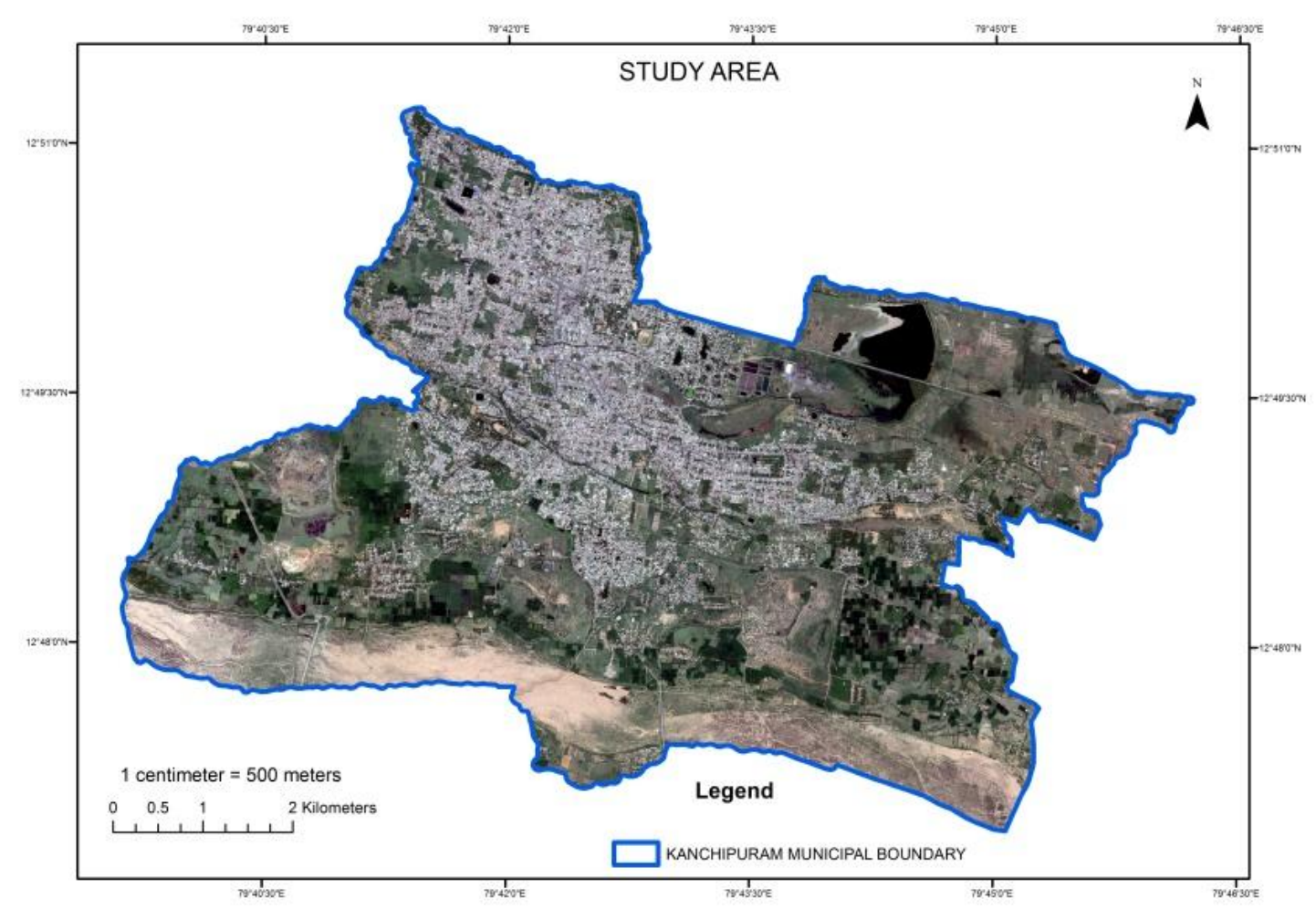

Figure 1. Map of study area

It has been identified both groundwater and soil gets polluted due to landfill activities in the surroundings of the present dump yard. Because of the high price in land value and environmental concern selection of alternative landfill in the study area is a complex process. In this case, the study was conducted to identify the potential alternative landfill site in the Kanchipuram municipality by using GIS technology. 


\section{Materials and Methods}

A field study was conducted primarily in existing landfill site to understand the reality in present dumping method. Both spatial and non-spatial data are essential to work in GIS platform, for that Kanchipuram boundary map was collected from the municipality to delineate the boundary of the municipality. An alternative landfill feasibility study has been conducted by using a GIS decision support tool (Kahvand et al., 2015). For preparing a base map of the study area, high resolution satellite imagery (quick bird) was used. From that prepared base map municipal boundary was extracted for further processing in GIS software. In India, the Central Public Health and Environmental Engineering Organisation (CPHEEO) provides the guidance for site selection of municipal solid waste. Thematic maps such as geology, geomorphology, residential, soil and road network was prepared for GIS analysis. According to the importance of each criterion, weights and rank assigned to AHP process.

Integration of GIS and AHP will produce the precious results when compared with the conventional method (Eskandari et al., 2013). The analysis results provide the spatial suitability for landfill in the study area. Based on that result further feasibility study was conducted to identify the best site for a landfill.

\section{Results and Discussion}

The identification of alternative landfill site is based on few criteria's such as restrictions and possibilities. These two criteria are evaluated properly in GIS to find the most suitable site for the landfill. CPHEEO provide restrictions such as $500 \mathrm{~m}$ around the habitation areas are not allowed for landfill sites and no landfill should be constructed in a critical habitat area. It is mandatory to follow the guidelines framed by the government for landfill site identification. Appropriate technique is required to identify the potential municipal landfill sites (Gbanie et al., 2013).

The second factor is possibilities of selecting landfill based on the favourable condition such as soil type, geology, accessibility of road network to the site etc., available in the study area. The legislation, restrictions and possibilities are differing from one location to another, but the methodology is applicable for all the projects. The analytic hierarchy process in a GIS platform was used to identify the alternative landfill site (Aydi et al., 2013).

\section{Residential Area Analysis}

The proximity study in GIS software was applied to identify the suitable landfill site in the study area. Identification of the best place for burial of solid waste is based on analysis of many parameters which should not lead the environmental pollution (Gorsevski et al., 2012) Initially residential areas were digitized in the satellite image to understand the permanent settlement and the availability of land in the study area. By using the buffer analysis tool $500 \mathrm{~m}$ buffer was created around the residential area as CPHEEO guidelines. Buffer analysis on polygon was applied to generate the buffer of existing boundary of residential area. Optimal siting for waste treatment facilities was identified by using GIS techniques (Tavares et al., 2011).

This buffer results helps to identify the available land in the study area for landfill purpose. Four potential sites are selected in the study area based on the favourable condition. The spatial information is useful for proper planning and decision making in 
selecting the site. The four alternative sites with its location and residential area in the municipality are shown in Fig. 2.

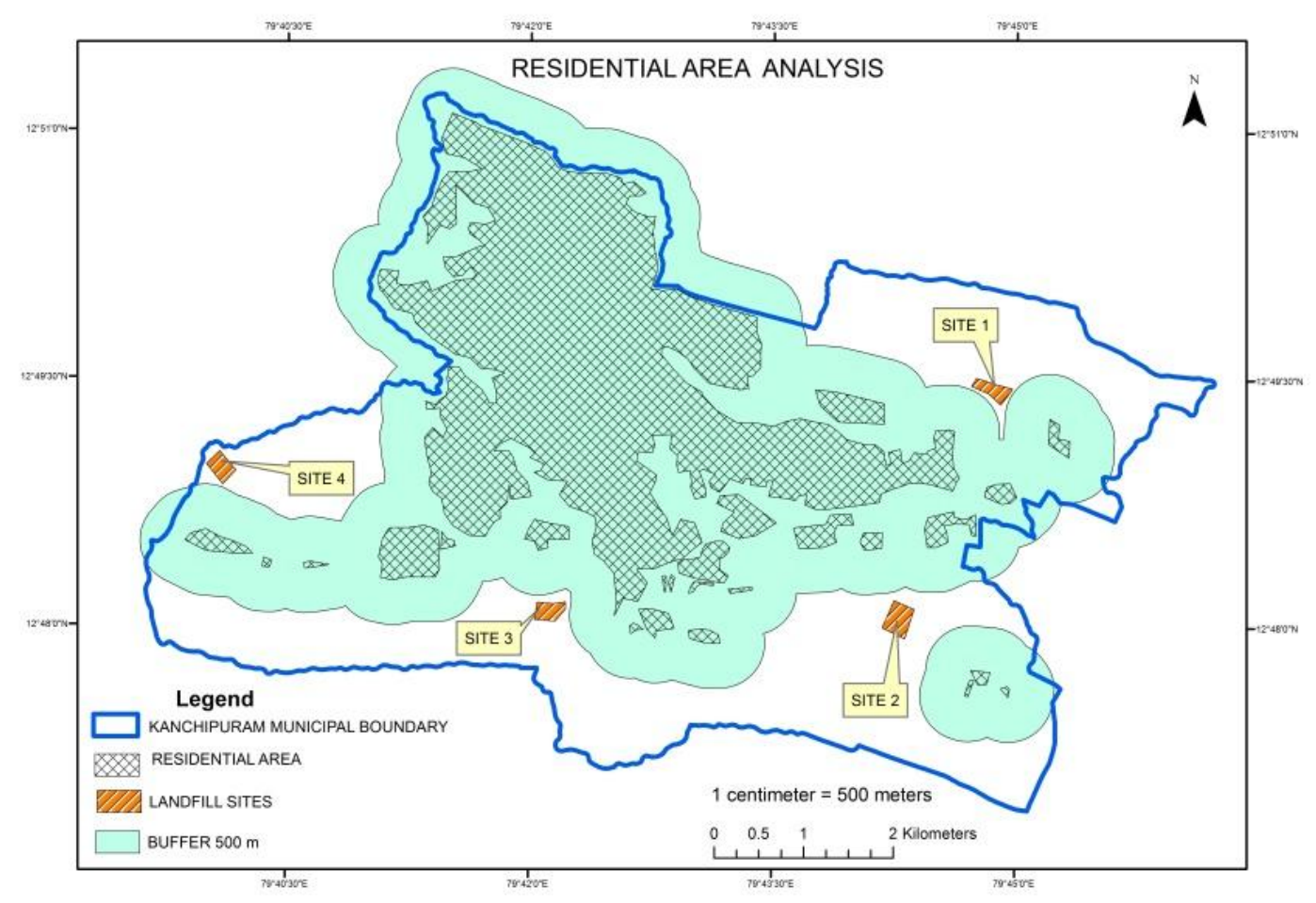

Figure 2. Map of residential area analysis

\section{Road Network Analysis}

The selected site must be suitable for transportation operation. Every day around 130 Mt solid waste has to be transported to the site, so that the road network facility to the alternative landfill site is an important condition.

As per CPHEEO guidelines for aesthetic reasons, no landfill site should be constructed within $200 \mathrm{~m}$ on the right of way of any state or national highway. Buffer zone in between the roads and landfill sites was adopted to identify the suitable site (Turkish Landfill Directive, 2012). In the study area state highway is there, so that $200 \mathrm{~m}$ buffer was created for state highways and identified the selected four potential sites are not falling within the buffer zone. All the selected four potential sites are full fill the road network accessibility (Fig. 3) in the municipality. Structural hierarchy was formed for the criteria like road, land uses, urban area and ecosystem to identify the suitable landfill site (Alavi et al., 2013).

Because of the proper road network the transportation of the solid waste made easy and time saving. In the prepared road network by using network analysis tools in ArcGIS software, it is possible to analyse origin and destination study for identifying the shortest path in the study area. This result will be useful for proper transportation planning for solid waste collection and transport to the dump yard. 


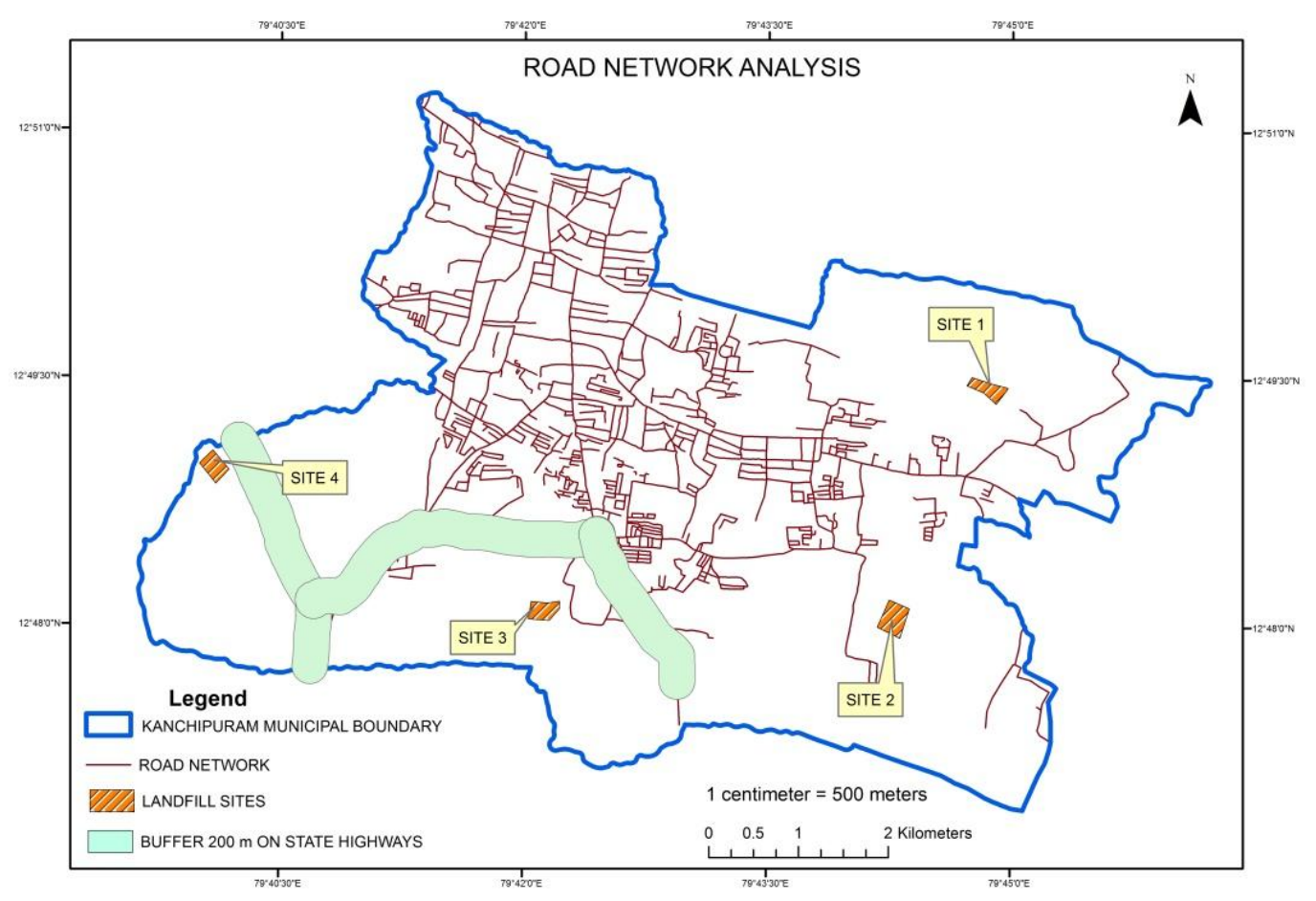

Figure 3. Map of road network analysis

\section{Geological Analysis}

The geological map is essential for identifying the geological settlement in the area. The presence of rock is a favourable condition for landfill site due to the impermeable of leachate. A bi-objective suitable model was developed for identifying the landfill location for municipal solid waste (Eiselt et al., 2014).

In the study area geological parameters such as gravel, sand, silt, sandstone with shale and coal partings are spatially distributed. Makan et al. $(2012,2013)$ was used PROMETHEE technique of suitable waste disposal site identification. Clay is considered as a most suitable ground for landfill due to its properties. In the absence of availability of suitable ground for landfill, it has been suggested to provide a compacted clay layer or suitable artificial materials to prevent the permeability of leachate. The suggested alternative four landfill locations are overlaid (Fig. 4) above the geology map by using an overlay analysis tool, it shows the presence of the geological feature below the landfill locations.

\section{Geomorphological Analysis}

The geomorphological map was used to recognize the water bodies, shallow flood plain, alluvial plain, moderately weathered/buried plain spatial distribution in the study area. Raster based GIS techniques was applied to identify the landfill (Yildirim, 2012). Site1landfill location fall on moderately weathered and buried plain area, site 2 landfill location falls on a shallow alluvial plain area, site3 landfill location falls on a shallow flood plain area and site4 landfills falls on a shallow alluvial plain area. This overlay analysis is useful for decision making to select the landfill site based on geomorphological condition. Structured query language (SQL) was utilised to retrieve the required 
information from the database. In this geomorphological analysis SQL was used to retrieve the geomorphological features from the entire database as shown in Fig. 5.

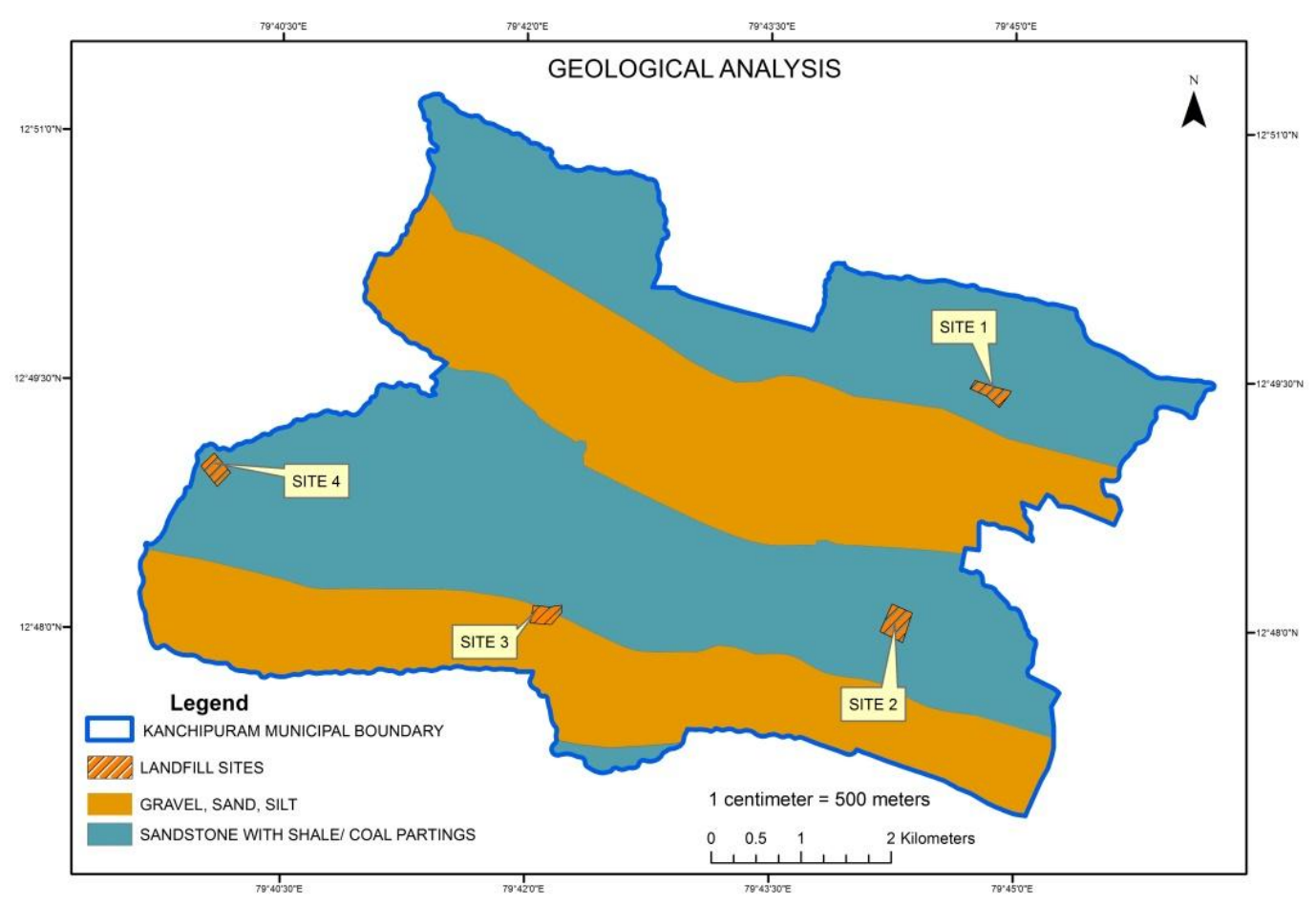

Figure 4. Map of geological analysis

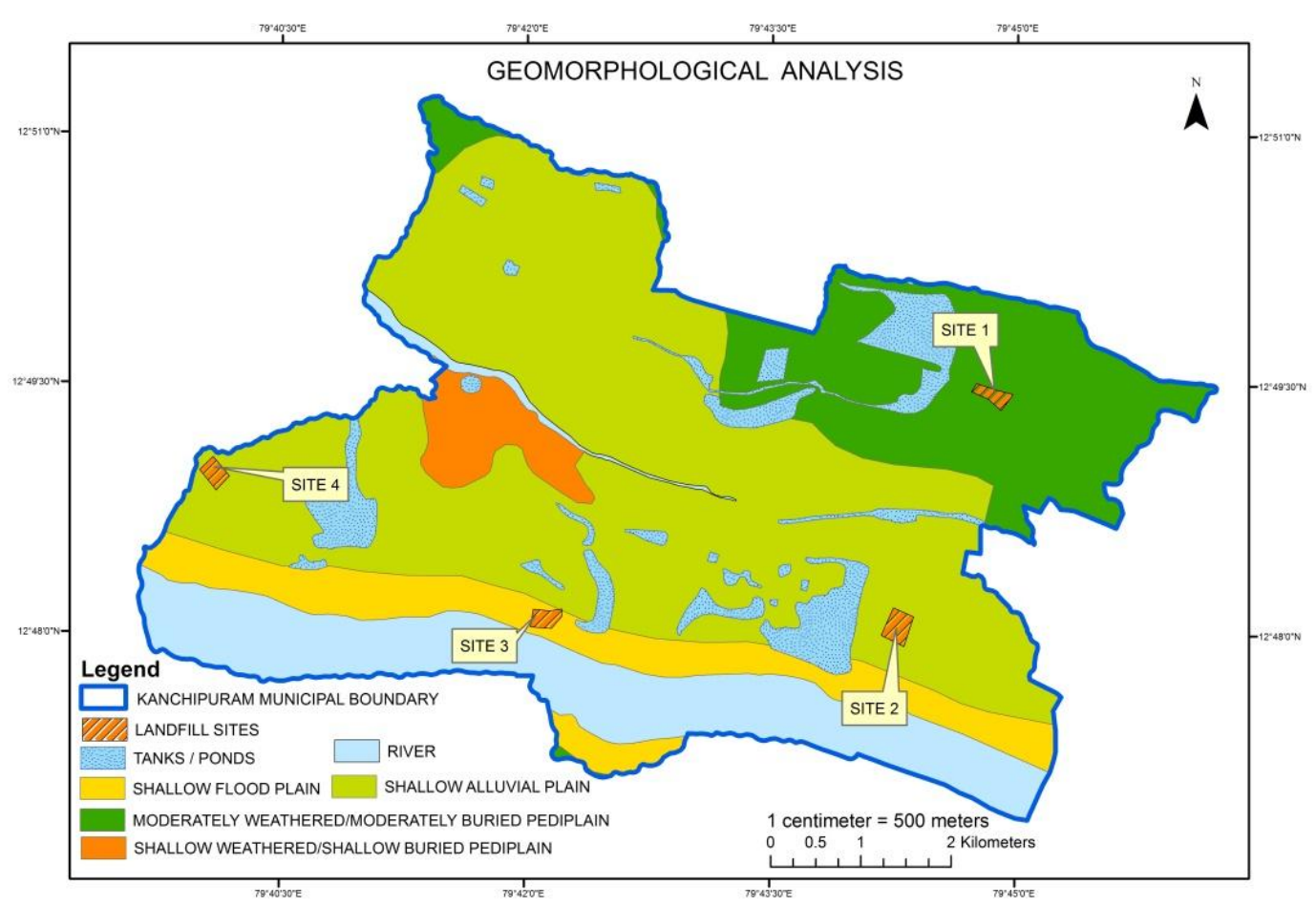

Figure 5. Map of geomorphological analysis 


\section{Soil Analysis}

The soil spatial distribution is identified in the study area by digitizing the soil map. The four potential alternative landfill sites are overlaid above the existing digitized soil map. In the study area five categories of soil (Fig. 6) are available and shown in the map. The landfill site1, site 2 and site 3 falls under sandy clay area. Clay is preferred as the most suitable ground for the landfill area (Istanbul Environmental Protection Company, 2014).

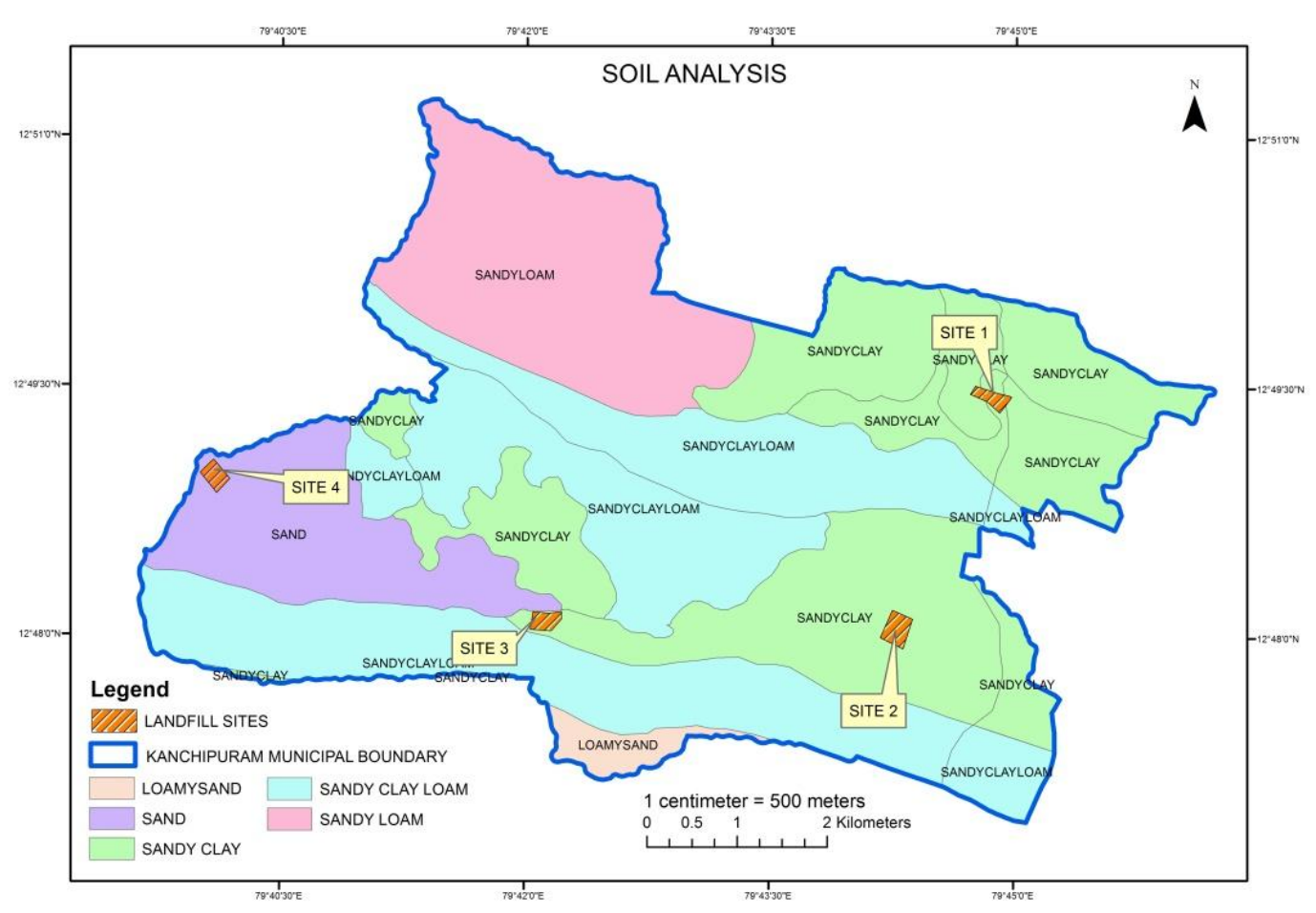

Figure 6. Map of soil analysis

The soil condition on site 4 is sand and this is not suitable for landfill as per CPHEEO guidelines. This overlay analysis was performed to identify the soil condition in the selected landfill sites for decision making.

\section{An AHP model for identifying a potential landfill site}

The alternative potential landfill site was identified by using the AHP method in GIS platform. Each layer was weighted and ranked based on its importance. By using GIS multi-criteria decision making technique the optimum landfill site selection was identified (Demir et al., 2016). In AHP analysis residential area, road network, geology, geomorphology and soil are considered. Cost minimization is possible by doing proper model (Eiselt et al., 2015). By using a model builder in ArcGIS software a model was developed for the above mentioned five parameters (Fig. 7).

A raster layer was created for each parameter after reclassification process, weighted and rank was assigned to each parameter. The analysis results produce the appropriate landfill based on the mathematical overlap of the analysis parameters. Based on the 
analysis result four zones are classified in the study area as, low priority zone, medium priority zone, high priority zone and very high priority zone.

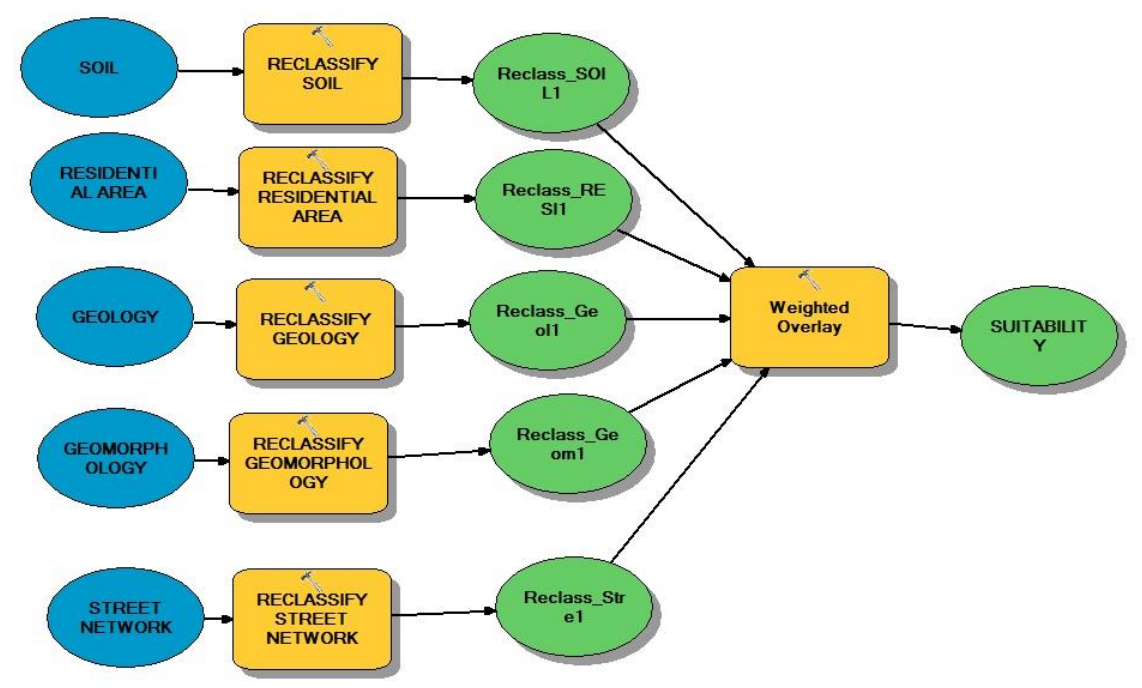

Figure 7. GIS model for landfill site selection

Overlaying various layers in GIS platform will produce a suitability map which shows the potential of each spatial location. The spatial location information is very much useful for decision making in landfill site selection. Justification of each alternative landfill site also made easier due to the AHP result. The prepared GIS model can be adopted in any municipalities for alternate landfill site identification. Based on the priority weighting and ranking may be adopted.

\section{Conclusions}

This study shows the potential of GIS analysis for identification of suitable alternative landfill sites. Integration of spatial and non-spatial data was effectively used to retrieve the appropriate results in landfill identification. Buffering results are clearly producing the spatial restriction of residential and road parameter based on CPHEEO. The AHP tool in GIS is used to identify five potential zones on the basis of priority. Out of the four potential zones, site 1 was identified as a very high priority zone, site 2 as low priority, site 3 as high priority and site 4 as medium priority. The AHP analysis resolves the decision making difficulties in an available large database. It has been identified, site 1 is located in northeast of Kanchipuram municipality where all the conditions are favourable for the optimum alternative landfill site. This developed decision support system will be useful for decision makers in solid waste management system to identify the suitable alternative landfill site.

Acknowledgments. The authors are thankful to SRM University, Kattankulathur, Chennai, Tamil Nadu, India for providing research facility. The authors wish their sincere thanks to SCSVMV University, Enathur, Kanchipuram, TamilNadu, India for valuable support. The authors also wish to record a deep sense of gratitude to Tamil Nadu Agricultural University, Thanjavur, Tamil Nadu, India. 


\section{REFERENCES}

[1] Alanbari, M. A., Al-Ansari, N., Jasim, H. K. (2014): GIS and multicriteria desision analysis forLandfill site selection in Al-Hashemiyah Qadaa. - NaturalScience 6: 282-304, http://dx.doi.org/10.4236/ns.2014.65032

[2] Alavi, N., Goudarzi, G., Babaei, A. A., Jaafarzadeh, N., Hosseinzadeh, M. (2013): Municipal solid waste landfill site selection with geographic information systems and analytical hierarchy process: a case study in Mahshahr County, Iran. - Waste Manag. Res 31(1): 98-105, DOI: 10.1177/0734242x12456092.

[3] Aydi, A., Zairi, M., Dhia, H. B. (2013): Minimization of environmental risk of landfill site using fuzzy logic, analytical hierarchy process, and weighted linear combination methodology in a geographic information system environment. - Environ Earth Sci. 68(5): 1375-1389

[4] Babalola, A., Busu, I. (2011): Selection of landfill sites for solid waste treatment in Damaturu town-using GIS techniques. - J Environ Prot 2(1):1-10, DOI: 10.4236/jep.2011.21001.

[5] Demesouka, O. E., Vavatsikos, A. P., Anagnostopoulos, K. P. (2013): Suitability analysis for siting MSW landfills and its multicriteria spatial decision support system: Method, implementation and case study. - Waste Management 33(5): 1190-1206, DOI: 10.1016/j.wasman.2013.01.030.

[6] Demir, G., Kolay, U. E., Okten, H. E., Alyuz, U., Bayat, C. (2016): Selection of alternative landfill location by using a Geographical information system. European side of istanbul. Case study. - Environ.Protect. Eng 42: 123-133

[7] Eiselt, H. A., Marianov, V. (2014): A bi-objective model for the location of landfills for municipal solid waste. - Eur J Oper Res 235(1):187-194

[8] Eiselt, H. A., Marianov, V. (2015): Location modeling for municipal solid waste facilities. - Comput Oper Res 62(1): 305-315

[9] Eskandari, M., Homaee, M., Mahmodi, S. (2012): An integrated multi criteria approach for landfill siting in a conflicting environmental, economical and socio-cultural area. Waste Manag 32(8): 1528-1538, DOI: 10.1016/j.wasman.2012.03.014.

[10] Eskandari, M., Homaee, M., Mahmoodi, S., Pazira, E. (2013): Integrating GIS and AHP for municipal solid waste landfill site selection. - J Basic Appl Sci Res 3(4): 588-595

[11] Gbanie, S. P., Tengbe, P. B., Momoh, J. S., Medo, J., Kabba, V. T. S. (2013): Modelling landfill location using Geographic Information Systems (GIS) and Multi-Criteria Decision Analysis (MCDA): Case study Bo, Southern Sierra Leone. - Applied Geography 36: 3-12, DOI: 10.1016/j.apgeog.2012.06.013.

[12] Gorsevski, P. V., Donevska, R., Mitrovski, C. D., Frizado, J. P. (2012): Integrating multicriteria evaluation techniques with geographic information systems for landfill site selection: A case study using ordered weighted average. - Waste Manag 32: 287-296, DOI: 10.1016/j.wasman.2011.09.023.

[13] Istanbul Environmental Protection Company (2014). - Personal Communication

[14] Kahvand, M., Gheitarani, N., Khanian, M., Ghadarjani, R. (2015): Urban Solid WasteLandfill Selection By Sdss. Case Study: Hamadan. - Environ.Protec.Eng 41(2): 47-55

[15] Makan, A., Malamis, D., Assobhei, O., Loizidou, M., Mountadar, M. (2012): Multicriteria decision analysis for the selection of the most suitable landfill site: case of Azemmour, Morocco. - Int J Manag Sci Eng Manag 7(2):96-109

[16] Makan, A., Malamis, D., Assobhei, O., Loizidou, M., Mountadar, M. (2013): Multicriteria decision aid approach for the selection of the best compromise management scheme for the treatment of municipal solid waste in Morocco. - Int J Environ Waste Manag 12(3):300-317 
[17] Sener, S., Sener, E., Karaguzel, R. (2011): Solid waste disposal site selection with GIS and AHP methodology: a case study in SenirkentUluborlu (Isparta) Basin, Turkey. Environ Monit Assess 173:533- 554

[18] Tavares, G., Zsigraiová, Z., Semiao, V. (2011): Multi-criteria GIS-based siting of an incineration plant for municipal solid waste. - Waste Manag. 31: 1960-1972

[19] Turkish Landfill Directive (2012). - Official Journal, Number: 27533

[20] Yildirim, V. (2012): Application of raster-based GIS techniques in the siting of landfills in Trabzon Province, Turkey: a case study. - Waste Manag Res 30(9):949-960 